Vol.45, Special n. : pp. 15-23, September 2002

ISSN 1516-8913 Printed in Brazil

\title{
Radiolabelled Cytokines for Imaging Chronic Inflammation
}

\author{
Alberto Signore*; Calogero D'Alessandria; Alessio Annovazzi and Francesco Scopinaro \\ Nu.M.E.D. Group; Nuclear Medicine; $2^{\text {nd }}$ Faculty of Medicine; University "La Sapienza"; Roma - Italy; \\ alberto.signore@uniroma1.it
}

\begin{abstract}
Diagnosis and particularly follow-up of chronic inflammatory disorders could be often difficult in clinical practice. Indeed, traditional radiological techniques reveal only structural tissue alterations and are not able to monitor functional changes occurring in tissues affected by chronic inflammation. The continuous advances in the knowledge of the pathophysioloy of chronic disorders, combined with the progress of radiochemistry, led to the development of new specific radiolabelled agents for the imaging of chronic diseases. In this scenario, cytokines, due to their pivotal role in such diseases, represent good candidates as radiopharmaceuticals.
\end{abstract}

Key words: Radiolabelled cytokines, chronic inflammation, imaging

\section{INTRODUCTION}

Nuclear medicine imaging of infection/inflammation represents nowadays the molecular imaging of different pathophysiological steps in inflammatory processes. New radiopharmaceuticals allow us to image not only the leukocyte migration and the exudation of macromolecules from the circulation due to the increased vascular permeability, but also the expression of specific receptors on the surface of granulocytes, lymphocytes and macrophages. Nuclear medicine imaging modality offer the unique opportunity to study the functional alteration occurring in the inflamed tissue and differs from other current imaging procedures such as X-ray computer tomography (CT) and magnetic resonance imaging (MRI), which supply high resolution information concerning the morphological changes that occur in inflammatory diseases. In addition, nuclear medicine techniques permit whole-body imaging, whereas $\mathrm{CT}$ and MRI routinely focus just a part of the body (Peters AM, 1998). The better understanding of the pathophysiology of the inflammatory process, together with the recent advances of radiochemistry, led to the development of different nuclear medicine techniques in the field of infection/inflammation (Chianelli et al. 1997).

Several radiopharmaceuticals are currently available for scintigraphic imaging of infection and inflammation (van der Laken et al. 1998). Scintigraphic imaging of inflammation can be achieved in two ways. First of all, radiolabelled molecules (i.e. albumin) which non-specifically accumulate in inflammatory foci due to the increased vascular permeability and exudation can be used. This approach is not particularly useful in chronic inflammatory disorders, in which the

\footnotetext{
* Author for correspondence
} 
exudation is minimal. A better alternative is to exploit the diapedesis and chemotaxis of leukocytes, either by radiolabelling patient's white blood cells ex vivo or by directly targeting leukocyte antigens or receptors in vivo, via administration of radiolabelled monoclonal antibodies $(\mathrm{MoAb})$ or receptors-binding ligands. The ideal radiopharmaceutical for imaging infection/inflammation should fulfil the following criteria:

- rapid accumulation in inflammatory foci;

- low physiological accumulation in organs (i.e. liver, spleen, gastrointestinal tract, kidneys) which can interfere with the scintigraphic visualisation of inflammation;

- rapid plasma clearance and increased retention in target tissues;

- possibility to discriminate between infection and sterile inflammation;

- absence or minimal pharmacological effects;

- low cost and ready-to-use preparation (Becker W et al., 2001).

Nevertheless, nowadays it is difficult to believe that there will be such an ideal radiopharmaceutical for imaging all types of inflammatory conditions. It is much more likely that we will have a panel of a few compounds to be used in different diseases and in different diseases stages.

The spectrum of inflammatory diseases has also changed over the last few years, hence the requirements for radionuclide imaging for the detection of inflammation are becoming more demanding so that, although gallium-67 and labelled leukocytes still remain useful agents for imaging acute inflammation and infections, there is currently great interest in the development of new agents especially for those able to target chronic inflammation.

Several new agents have been proposed in the past 10 years. Most of them, however, are very promising in vitro and in animal models but turn to be less useful when experimented in humans. This is particularly true for agents designed for imaging chronic inflammation, being the pathophysiology in humans very different from the animal models currently available.

Therefore, with few exceptions $\left({ }^{67} \mathrm{Ga},{ }^{111} \mathrm{In}\right.$ octreotide), most of the radiopharmaceuticals nowadays commercially available are designed for imaging acute inflammation and infection, raising the rationale for development of new specific agents for chronic inflammation imaging.

\section{CYTOKINES}

Cytokines are proteins and glicoproteins, members of a family molecule with important roles in the homeostatic control of the immune system and of pathophysiology of different organs. Cytokines play an important role in the different phases of the immune response: induction and outcome of the inflammatory process, regulation of the acute phase response, initiation of lymphocyte activation, control of antibody production and/or generation of cytotoxic lymphocytes. Cytokines are also involved in the control of the neoplastic disorders acting both as tumor growth inhibitors and as tumor growth factors (Oppenheim $\mathrm{J}$ et al., 1996). Most cytokines have a molecular weight between 15 and $25 \mathrm{kDa}$ and are often similar in size, charge and glycosylation. The activation of the immune system is largely orchestrated by cytokines that in turn regulate different genes and the expression of surface molecules with specific functions. These soluble factors act as intercellular messenger between cells of the immune system by binding to specific receptors that are normally poorly expressed on effector cells but that are upregulated following cell activation. Different cell types produce the same receptor for the same cytokine thus creating a network in which different cells produce, for a short period of time, a large variety of cytokines able to bind and stimulate different cells (Table 1). Cytokine receptors, consisting of two or more membrane protein subunits, can be separated in different classes including the hematopoietin receptor superfamily (e.g. receptor for IL-2, -4, -5, -6, GM-CSF etc), the TNF receptor superfamily, the Ig receptor superfamily (IL-1R), the IFN receptor superfamily 
etc. Dimerisation of cytokine receptor subunits leads to the activation of the receptor associated cytoplasmic protein tyrosine kinases (JAKs) that recruit members of the STAT family or activate the Ras-mitogen pathways (Curfs JH et al., 1997).

Table 1 - Source, stimulus and action of most relevant cytokines

\begin{tabular}{|c|c|c|c|c|}
\hline Cytokines & Source & Stimulus & Primary actions & Major target cells \\
\hline $\mathrm{TFN} \alpha$ & Macrophages & $\begin{array}{l}\text { Sepsis, } \\
\text { ischemia, TNF } \alpha\end{array}$ & $\begin{array}{l}\text { Proinflammatory via } \\
\text { feedback induction of } \\
\text { TNF } \alpha, \text { IL-1 } \beta \\
\text { chemokines production } \\
\text { - Cardiodepressant } \\
\text { - } \text { Causes cachexia } \\
\text { - Promotes apoptosis }\end{array}$ & $\begin{array}{ll}\text { TNF-R1= } \\
\text { ubiquitously } \\
\text { expressed } \\
\text { TNF-R2= } \\
\text { hematopoietic } \\
\text { cells, En }\end{array}$ \\
\hline IL-1 $\beta$ & $\begin{array}{l}\text { Macrophages, } \\
\text { endothelial } \\
\text { cells }\end{array}$ & Sepsis, ischemia & $\begin{array}{l}\text { Proinflammatory via } \\
\text { induction of TNF } \alpha, \text { IL- } \\
1 \beta, \text { COX-2 and iNOS } \\
\text { - } \quad \text { Synergizes with TNF } \alpha \\
\text { - } \\
\text { - } \\
\text { Induces adhesion } \\
\text { molecule (ICAM-1) } \\
\text { expression }\end{array}$ & 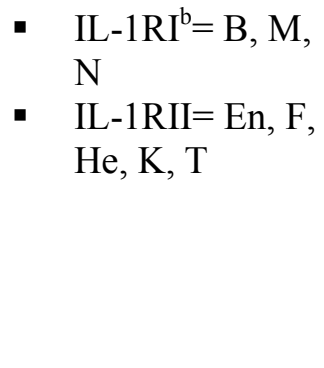 \\
\hline IL-2 & T-lymphocytes & Sepsis, ischemia & $\begin{array}{l}\text { - Growth factor for T- } \\
\text { lymphocytes and natural } \\
\text { killer cells } \\
\text { - Induces proliferation and } \\
\text { activation of lymphokine } \\
\text { activated killer (LAK) } \\
\text { cells. }\end{array}$ & - $\quad \mathrm{T}, \mathrm{B}, \mathrm{NK}$ cells \\
\hline IL-6 & $\begin{array}{l}\text { Macrophages, } \\
\text { T-lymphocytes }\end{array}$ & $\begin{array}{l}\text { Sepsis, TNF } \alpha \text {, } \\
\text { and IL-1 } \beta\end{array}$ & $\begin{array}{l}\text { Can be both pro- and } \\
\text { anti-inflammatory } \\
\text { - Endogenous pyrogen } \\
\text { Mediates hepatic acute } \\
\text { phase response } \\
\text { - Used as an index of } \\
\text { magnitude of systemic } \\
\text { inflammation }\end{array}$ & $\begin{array}{l}\text { - B, T, He, HP, } \\
\text { N cells }\end{array}$ \\
\hline IL-7 & $\begin{array}{l}\text { Stromal cells, } \\
\text { E }\end{array}$ & Sepsis & $\begin{array}{l}\text { Maturation of T, B; } \\
\text { PAK }\end{array}$ & $\begin{array}{l}\text { - Pre-T and pre- } \\
\text { B cells }\end{array}$ \\
\hline IL-8 & Macrophages & $\begin{array}{l}\text { TNF- } \alpha \text { and IL- } \\
1 \beta\end{array}$ & $\begin{array}{l}\text { A chemokine which } \\
\text { recruits and activates } \\
\text { neutrophils } \\
\text { Also used as an index of } \\
\text { magnitude of systemic } \\
\text { inflammation. }\end{array}$ & $\begin{array}{l}\text { - Neutrophil } \\
\text { cells }\end{array}$ \\
\hline IL-10 & T-lymphocytes & Sepsis, TNF $\alpha$ & $\begin{array}{l}\text { Anti-inflammatory via } \\
\text { inhibition of TNF } \alpha / \mathrm{IL}- \\
1 \beta \text { production and NF- } \\
\kappa \mathrm{B} \text { translocation }\end{array}$ & $\begin{array}{l}\text { - T, B precursor } \\
\text { cells } \\
\text { - Macrophage } \\
\text { cells }\end{array}$ \\
\hline
\end{tabular}


Cont. Table 1

\begin{tabular}{|c|c|c|c|c|}
\hline Cytokines & Source & Stimulus & Primary actions & Major target cells \\
\hline IL-11 & $\begin{array}{l}\text { Fibroblasts, } \\
\text { epithelial cells }\end{array}$ & $\begin{array}{l}\text { Sepsis, TNF } \alpha \text {, } \\
\text { IL- } 1 \alpha \text {, TGF } \beta\end{array}$ & $\begin{array}{l}\text { Anti-inflammatory via } \\
\text { inhibition of TNF } \alpha, \text { IL- } \\
1 \beta \text { production } \\
\text { endothelial cells } \\
\text { - Hematopoietic growth } \\
\text { factor } \\
\text { Induces hepatic acute } \\
\text { phase response }\end{array}$ & - $\quad$ HP, Meg, Pla \\
\hline IL-12 & $\begin{array}{l}\text { Macrophages, } \\
\text { dendritic cells }\end{array}$ & Sepsis & $\begin{array}{l}\text { Proinflammatory via } \\
\text { induction of TNF } \alpha \text { and } \\
\text { interferon- } \gamma \text { neutrophils } \\
\text { - Synergistic with IL-18 } \\
\text { - Induces differentiation of } \\
\text { TH1 cells } \\
\text { - Activates neutrophils }\end{array}$ & - $\quad \mathrm{T}, \mathrm{NK}$ cells \\
\hline IL-18 & Macrophages & $\begin{array}{l}\text { Sepsis, } \\
\text { ischemia, TNF } \alpha\end{array}$ & 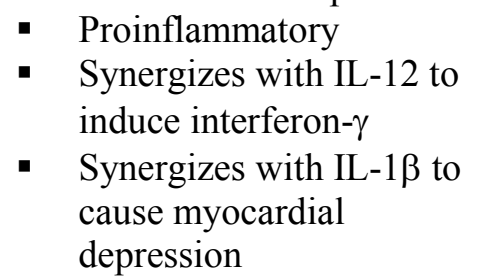 & - $\mathrm{T}, \mathrm{NK}$ cells \\
\hline IL-13 & $\mathrm{T}$ cells & $\begin{array}{l}\text { Allergy, } \\
\text { inflammation }\end{array}$ & $\begin{array}{l}\text { - Growth/differentiation of } \\
\text { B cells } \\
\text { - Anti-inflammatory } \\
\text { activity }\end{array}$ & - $\quad \mathrm{B}, \mathrm{NK}, \mathrm{M}$ cells \\
\hline IL-15 & $\begin{array}{l}\text { macrophages, } \\
\text { muscle cells, } \\
\text { keratinocytes, } \\
\text { renal epithelial } \\
\text { cells, } \\
\text { endothelial } \\
\text { cells, }\end{array}$ & Inflammation & 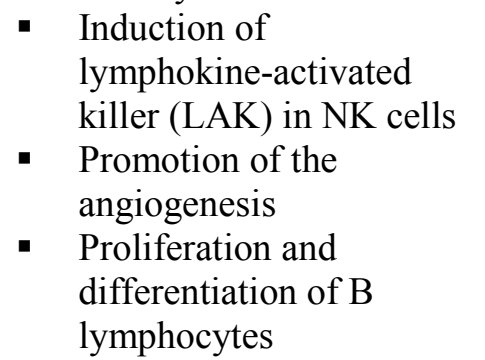 & - $\quad \mathrm{T}, \mathrm{B}, \mathrm{NK}$ cells \\
\hline IFN- $\alpha$ & $\begin{array}{l}\mathrm{T}, \mathrm{B}, \mathrm{NK}, \\
\text { monocytes } \\
\text { macrophages, } \\
\text { fibroblast cells }\end{array}$ & Virus infection & $\begin{array}{l}\text { - Antiviral/antiparasitic } \\
\text { action } \\
\text { - Activation of } \\
\text { macrophages, NK, Tc, B } \\
\text { cells }\end{array}$ & $\begin{array}{l}\text { - Many different } \\
\text { cells }\end{array}$ \\
\hline IFN- $\beta$ & $\begin{array}{l}\text { Virus-infected } \\
\text { cells, } \\
\text { fibroblasts, } \\
\text { endothelial } \\
\text { cells, } \\
\text { macrophages }\end{array}$ & Virus infection & $\begin{array}{l}\text { - Antiviral action } \\
\text { Activation of } \\
\text { macrophage and NK } \\
\text { cells }\end{array}$ & $\begin{array}{l}\text { - Many different } \\
\text { cells }\end{array}$ \\
\hline IFN- $\gamma$ & $\begin{array}{l}\mathrm{T}, \mathrm{NK} \text {, } \\
\text { endothelial } \\
\text { cells }\end{array}$ & Virus infection & $\begin{array}{l}\text { Inhibition of cell growth } \\
\text { Activation of monocytes, } \\
\text { macrophages, NK cells } \\
\text { and fibroblasts }\end{array}$ & $\begin{array}{l}\text { - Many different } \\
\text { cells }\end{array}$ \\
\hline
\end{tabular}


RADIOLABELLED CYTOKINES FOR IMAGING CHRONIC INFLAMMATION

Radiolabelled cytokines are a class of peptide radiopharmaceuticals that have diagnostic potential as specific receptor ligand in several pathological conditions. Several cytokine/cytokine receptor systems operate in infection, autoimmunity, cancer and other pathological conditions. This enhanced receptor expression provides a target for the diagnosis of the inflammatory disease and tumours (Weiner RE et al., 1999). Many cytokines show features which favour their use as radiopharmaceuticals; these include a relatively low molecular weight, a short half life and a rapid plasma clearance, binding of high affinity to specific receptors, ready availability due to recombinant technology and lack of immunogenicity (Table 2).

Table 2 - Radiolabelled cytokines to study inflammation/infection

\begin{tabular}{|c|c|c|}
\hline Cytokines & Isotope chosen for labelling & Clinical use \\
\hline IL-1 $\beta$ & $125-\mathrm{I}$ & $\begin{array}{l}\text { Infectious foci (abscesses) sterile inflammation in } \\
\text { animal model }\end{array}$ \\
\hline IL-1 $\beta$ & 123-I & $\begin{array}{l}\text { Infectious foci (abscesses) sterile inflammation in } \\
\text { animal model }\end{array}$ \\
\hline $\begin{array}{l}\text { IL-1ra (receptor } \\
\text { antagonist) }\end{array}$ & $123-\mathrm{I}$ & $\begin{array}{l}\text { Infectious foci (abscesses) sterile inflammation in } \\
\text { animal model }\end{array}$ \\
\hline IL-2 & 35-S, 131-I, 123-I, 99m-Tc & $\begin{array}{l}\text { Detection of chronic infiltration in animal model } \\
\text { and in humans }\end{array}$ \\
\hline $\begin{array}{l}\text { IL-6, IL-10, } \\
\text { G-CSF, IFN- } \gamma\end{array}$ & $125-\mathrm{I}$ & Infectious foci in animal model \\
\hline IL-8 & $125-\mathrm{I}$ & $\begin{array}{l}\text { Detection of infectious foci (abscesses), sterile } \\
\text { inflammation and osteomyelitis in animal model } \\
\text { and in humans }\end{array}$ \\
\hline IL-12 p40 & $125-\mathrm{I}$ & $\begin{array}{l}\text { Detection of lymphocytes infiltrates in animal } \\
\text { models }\end{array}$ \\
\hline IFN- $\gamma$ & $123-\mathrm{I}$ & Lung inflammatory diseases \\
\hline EGF & $123-\mathrm{I}$ & Metastatic limph nodes \\
\hline
\end{tabular}

\section{Interleukin-2}

Interleukin-2 is a small single-chain glycoprotein $(15.5 \mathrm{kDa})$ of 133 amino acid, synthesised and secreted, in vivo, by lymphocytes following specific stimulation. Several pathological condition, such as autoimmune diseases, graft rejection and even tumours, are characterised by chronic infiltration of the target tissue by lymphomononuclear cells (Semenzato et al., 1992). It acts via binding to a specific receptor that is expressed on activated $\mathrm{T}$ cells and that plays a central role in maintaining the immune response by promoting the long-term proliferation of activated $\mathrm{T}$ cells. In addiction it promote the proliferation and differentiation of $\mathrm{B}$ cells, NK cells and macrophages (Smith KA, 1988). In physiological condition the expression of IL-2R on peripheral blood lymphocytes and in lymphoid tissue is negligible (Robb RJ et al., 1984). Following activation, infiltrating cells express the IL2R on their surface membrane, thus suggesting the use of radiolabelled IL-2 for the in vivo detection of mononuclear cell infiltration. ${ }^{123} \mathrm{I}$ and ${ }^{99 \mathrm{~m}} \mathrm{Tc}$-labelled IL-2 has been extensively used to image T-lymphocytes and monocytes in chronic, mononuclear-cell mediated, inflammatory processes such as autoimmune diseases, kidney graft rejection and melanoma characterised by an over-expression of CD25 (interleukin-2 receptor) (Table 3).

In clinical studies it has been possible to ascertain that scintigraphy with radiolabelled IL2 specifically detects activated lymphocytes, correlates with the severity of tissue lymphocytic 
infiltration and can be used for monitoring the efficacy of therapies. In humans, after i.v. injection, radiolabelled IL2 accumulates in sites of pathological infiltration following the binding to high affinity IL2R bearing cells and could be detected in vivo by the external detection of radioactivity by gamma camera imaging. Scintigraphy with radiolabelled IL2, therefore, aims to highlight the presence of $\mathrm{T}$ lymphocyte activation in tissues and might be used for the diagnosis of the state of activity of immune mediated processes. IL2, both labelled with ${ }^{123} \mathrm{I}$ and ${ }^{99 \mathrm{~m}} \mathrm{Tc}$, has been used in different pathological conditions and in particular it has been extensively studied in patients affected by Coeliac disease (Signore et al. 2000a), Crohn's disease (Signore et al. 2000b), Type 1 diabetes (Signore et al. 1996, Signore et al. 1999), autoimmune thyroid disease, Sjogren syndrome and cutaneous melanoma (Barone et al. 1998).

Table 3 - Clinical applications of radiolabelled Interleukin-2 scintigraphy

\begin{tabular}{lcc}
\hline \multicolumn{1}{c}{ Disease } & Radiopharmaceutical & Reference \\
\hline Graves' ophthalmopathy & $123-\mathrm{I}$ & Rendl et al. 2000 \\
Type 1 diabetes & $123-\mathrm{I}$ & Signore et al. 1996 \\
Celiac disease & $123-\mathrm{I}$ & Signore et al. 2000 \\
Crohn's disease & $123-\mathrm{I}$ & Signore et al. 2000 \\
Type 1 diabetes in mice & $125-\mathrm{I}$ & Rolandsson et al. 2001 \\
Thyroid autoimmune diseases & $99 \mathrm{mTc}$ & Procaccini et al. 1998 \\
Kidney graft rejection & $123-\mathrm{I}$ & Abbs et al. 1993 \\
Cutaneous melanoma & $99 \mathrm{mTc}$ & Barone et al. 1998 \\
\hline
\end{tabular}

\section{Use of radiolabelled-IL2 in IDDM}

Type-1 diabetes mellitus is the consequence of pancreatic beta-cell destruction mediated by mononuclear cells (insulitis). The insulitis process starts since many years before the onset of clinical manifestations of the disease. The presence of insulitis could be only suspected in subjects "at risk" to develop autoimmune diabetes (relatives of patients affected by type I diabetes, who present positivity to disease-specific autoantibodies). Nevertheless, no tool is currently available to detect such pancreatic infiltration. This could be particularly useful in order to select patients who can benefit of specific preventive immunotherapies. In a pilot study, ${ }^{123}$ I-IL2 was able to correctly identify the insulitis process in 5 subjects at risk to develop type I diabetes (Signore et al. 2002). All these subjects developed diabetes within 4 years from the scintigraphy. At time of diagnosis, pancreatic beta-cell inflammation is present only in a subgroup of type 1 diabetic patients (approximately 50\%). In a recent study

${ }^{99 \mathrm{~m}} \mathrm{Tc}-\mathrm{IL} 2$ scintigraphy correctly identified this subgroup of patients. Indeed, those patients positive to IL2 scan, presented a better metabolic control after 1-year treatment with nicotinamide (Chianelli et al. 2000). These results suggest that treatment with specific immunotherapies can be useful only if a lymphocytic infiltration is still active in endocrine pancreas.

\section{Use of radiolabelled-IL2 in Coeliac disease}

Coeliac disease is a mucosal cell-mediated immune pathology and represents one of the few immune mediated diseases in which a well characterised antigen has been recognised as the ethiologic agent. Immunohistochemical studies of tissue biopsies in Coeliac disease patients revealed that the jejunal mucosa is infiltrated mainly by Tlymphocytes expressing the interleukin-2 receptors (IL2R) as sign of T-cell activation (Maiuri et al., 1996). ${ }^{123}$ I-IL2 scintigraphy has been tested in 10 coeliac disease patients at time of diagnosis. All these subjects showed a significant ${ }^{123}$ I-IL2 small bowel uptake (Signore et al. 2000a). The autoradiography performed on jejunal biopsies confirmed that this radiopharmaceutical specifically binds only to IL2 receptors-bearing activated cells. ${ }^{123}$ I-IL2 scintigraphy was repeated in 7 patients after 1 year of gluten-free diet. Interestingly, in 2 out of 7 patients, although ${ }^{123} \mathrm{I}-$ IL2 bowel uptake was significantly lower as compared to the first scan, the scintigraphy still remained positive in a localised area of the bowel. Results obtained in this study, suggests that IL2 scintigraphy could be used in patients affected by 
coeliac disease to monitor the efficacy of the gluten-free diet.

\section{Use of radiolabelled-IL2 in Crohn's disease}

Crohn's disease (CD) is a relapsing/remitting immune disease that can involve the whole gut. In $\mathrm{CD}$, a significant increase in the percentage of activated mononuclear cells expressing the interleukin-2 (IL2) receptor have been reported both in circulation and intestinal mucosa (Choy et al. 1990). The use of radiolabelled IL2 has been tested in different stages of $\mathrm{CD}$ to understand the possible clinical utility of this new imaging tool.

In a previous longitudinal study ${ }^{123}$ I-IL2 scintigraphy was able to reveal areas of bowel infiltrated by activated $\mathrm{T}$ lymphocytes, in 15 patients both with active and with an early offsteroid or steroid-induced remission CD. Interestingly, the degree of ${ }^{123}$ I-IL2 bowel uptake, inversely correlates with time free from recurrence. In this view, ${ }^{123}$ I-IL2 scintigraphy could represent an ideal image modality to reach this aim (Signore et al. 2000b).

In the same study, 6 patients have been restudied after 3 months of steroid therapy. Despite the steroid-induced remission (CD activity index $<150$ ) still there were some patients with positive IL2 uptake. This subgroup of patients relapsed again, suggesting that steroid therapy should be prolonged, if a non-symptomatic gut inflammation is still present. In a different study, ${ }^{99 \mathrm{~m}} \mathrm{Tc}$-labelled IL2 has been studied in 33 patients affected by CD in stable remission ( $>12$ months). Although more than $60 \%$ of patients showed a positive ${ }^{99 \mathrm{~m}}$ Tc-IL2 scan, in such patient population ${ }^{99 \mathrm{~m}} \mathrm{Tc}-\mathrm{IL} 2$ scintigraphy showed a low positive predictive value $(0,44)$ in predicting future disease relapses (Annovazzi et al. 1999). Indeed a negative ${ }^{99 \mathrm{~m}} \mathrm{Tc}-$ IL2 scan could exclude the onset of a disease relapse at least for 12 months (high negative predictive value).

\section{Use of radiolabelled-IL2 in melanoma}

Tumor infiltrating lymphocytes are often observed at histological evaluation of cutaneous melanoma. The infiltration represents the immune reaction to the tumour. In a pilot study, ${ }^{99 \mathrm{~m}} \mathrm{Tc}-\mathrm{IL} 2$ scintigraphy allowed the in vivo measurement of IL2R+ve cells infiltrating melanoma lesions suggesting its use for prognostic purposes and to select patients who may benefit of IL2 immunotherapy (Barone et al.1998).

\section{Interleukin-12}

A relevant clinical issue is the possibility to differentiate between T-helper 1 (Th1) and Thelper 2 (Th2) mediated inflammation: Th1 lymphocytes are more aggressive than the Th2 cell subtype, leading to the destruction of inflamed tissues. Interleukin-2, by binding the IL2 receptor, mainly expressed by activated Th1 lymphocytes, proved to be suitable for in vivo study of Th1mediated inflammation, although it binds to both Th1 and Th2 cells. In order to increase the specificity for the detection of Th1-mediated inflammation (i.e. organ-specific autoimmune diseases), the potentiality of radiolabelled IL12 as a new radiopharmaceutical has been considered. IL12 is a cytokine that promote the differentiation of $\mathrm{T}$ lymphocytes through the Th1 pattern. Interleukin 12 is a heterodimeric cytokine made up of two chains (p53 and p40) which induces IFN- $\gamma$ production by $\mathrm{T}$ and NK cells, enhances NK and ADCC activity and co-stimulates peripheral blood lymphocyte proliferation (Manetti R et al., 1993). ${ }^{125}$ I-labelled IL12-p40, (single chain of the IL12 molecule without biological activity) showed the ability to bind the IL2R in vitro with a similar affinity as compared to the unlabelled monomer, although with low affinity than the etero-dimeric cytokine (Barone $R$ et al., 1998). ${ }^{125}$ I-IL12p40, showed specific binding to IL12 receptor-bearing cells, previously injected in the thigh of Balb/c mice. Further studies are ongoing.

\section{FUTURE PERSPECTIVES}

Despite radiolabelled IL-2 is an excellent and valuable radiopharmaceutical for diagnostic purposes, the labelling procedure remain tedious, expensive and time consuming due to the poor solubility and stability of this cytokine. It is therefore important to identify other possible candidate cytokines that could efficiently be used for the in vivo detection of lympho-mononuclear cells. Moreover, as mentioned above, it would be interesting to differentiate between Th1 and Th2mediate inflammation, since new specific immunotherapies aim to "shift" Th1 vs Th2 chronic inflammation rather than suppress the 
lymphocytic infiltration. In this respect, the possibility of radiolabelling specific Th1 (I-TAC) and Th2 (eotaxin-2) cytokines is being investigated.

\section{RESUMO}

O diagnóstico, e particularmente o acompanhamento das doenças inflamatórias crônicas, pode ser freqüentemente muito difícil na prática clínica. As técnicas radiológicas tradicionais revelam somente as alterações teciduais estruturas, não sendo capazes de monitorar as alterações funcionais que ocorrem nesses tecidos afetados pela inflamação crônica. $\mathrm{O}$ contínuo avanço no conhecimento da fisiopatologia dessas doenças, combinado com o progresso da radioquímica, levou ao desenvolvimento de novos agentes radiomarcados para a obtenção de imagens de doenças crônicas. Nesse cenário, as citocinas, devido ao papel primordial em tais doenças, apresentam-se como fortes candidatas a radiofármacos.

\section{REFERENCES}

Abbs, I. C.; Pratt, J. R.; Dallman, M. J. and Sacks, S. H. (1993), Analysis of activated T cell infiltrates in rat renal allografts by gamma camera imaging after injection of 123-iodine-interleukin 2. Transplant Immunology; 1, 45-51.

Annovazzi, A. Biancone, L. Caviglia, R. Rossi, M. Chianelli, M. Parisella, M. Montesano, T. Stochino, M. Mather, S. and Signore, A. (1999), Comparison between ${ }^{99 \mathrm{~m}}$ Tc-HMPAO granulocyte and ${ }^{99 \mathrm{~m}}$-Tc-IL2 scintigraphy in Chron's disease. (Abstract). Eur. J. Nucl. Med., 26, 1110.

Barone, R.; Chianelli, M.; Nardi, G.; Parisella, M. G.; Di Leve, G.; Mire Sluis, A. and Signore, A. (1998), Radiolabelled interleukin-12 p40. A new radiopharmaceutical for imaging chronic TH1mediated inflammation. (abstract) Q. J. Nucl. Med.; 42 : (suppl. 1), 77.

Barone, R.; Chianelli, M.; Procaccini, E.; Annovazzi, A.; Bottoni, U.; Panetta, C.; Innocenzi, D.; Calvieri, S. and Signore A. (1998), ${ }^{99 \mathrm{~m}}$ Tc-IL2 scintigraphy in patients with cutaneous melanoma: detection of lymphocytic infiltration. Eur. J. Nucl. Med., 25, 896. [Abstract].

Becker, W. and Meller, J. (2001), The role of nuclear medicine in infection and inflammation. The Lancet Infectious Diseases, 1, 326-333.
Chianelli, M.; Mather, S. J.; Martin-Comin, J. and Signore, A. (1997), Radiopharmaceuticals for the study of inflammatory processes: a review. Nucl. Med. Commun., 18 (5), 437-55.

Chianelli, M.; Parisella, M. G.; Mather, S. J.; Annovazzi, A.; Capriotti, G.; D'Ignazio, L.; Montesano, T.; Ronga, G. and Signore, A. (2000), ${ }^{99 m}$ Tc-IL2 scintigraphy predicts response to immunotherapy in newly diagnosed type 1 diabetes patients. Eur. J. Nucl. Med., 27, 936. [Abstract].

Choy, M. Y.; Walker-Smith, J. A.; Williams, C. N. and McDonald, T. T. (1990), Differential expression of CD25 (interleukin-2 receptor) on lamina propria $T$ cells and machrophages in the intestinal lesions in Crohn's disease and ulcerative colitis. Gut, 31, 1365-1370.

Curfs, J. H.; Meis, J. F. and Hoogkamp-Korstanje, J. A. (1997), A primer on cytokines: sources, receptors, effects, and inducers. Clinical Microb. Rev., 10, 742-780.

Frans, H. M. and Corstens, Jos W. M. van der Meer (1999), Nuclear medicine's role in infection and inflammation. The Lancet, 354, 765-770.

Maiuri, L.; Picarelli, A.; Boirivant, M.; Coletta, S.; Mazzilli, M. C.; De Vincenzi, M.; Londei, M. and Auricchio, S. (1996), Definition of the initial immunologic modifications upon in vitro gliadin challenge in the small intestine of coeliac patients. Gastroenterology, 110, 1368-1378.

Manetti, R.; Parronchi, P.; Giudizi, M. G.; Piccinni, M. P.; Maggi, E.; Trinchieri, G. and Romagnani, S. (1993), Natural Killer cell stimulatory factor (interleukin $12\{\mathrm{IL} 12\}$ ) induces $\mathrm{T}$ helper type 1 (Th1)-specific immune responses and inhibits the development of IL-4-producing Th cells. J. Exp. Med., 177, 1199-1204.

Oppenheim, J. (2001), Cytokines: past, present and future. Int. J. Hematol., 7,33-8.

Oppenheim, J. and Fujiwara, H. (1996), The role of cytokines in cancer. Cytokine \& Growth Factor Review, 7, 279-288.

Pallone, F.; Fais, S.; Squarcia, O.; Biancone, L.; Pozzilli, P. and Boirivant, M. (1987), Activation of peripheral blood and intestinal lymphocytes in Crohn's Disease: in vivo state of activation and in vitro response to stimulation as defined by the expression of early activation antigens. Gut, 28, 745-753.

Peters, A. M. (1998), The use of nuclear medicine in infections. Br. J. Radiol., 71 : (843), 252-261.

Procaccini, E.; Chianelli, M.; Parisella, M. G.; Barone, R.; Di Leve, G.; Grossmann, A. and Signore, A. (1998), ${ }^{99 m}$ Tc-IL2 scintigraphy in autoimmune thyroid diseases. Eur. J. Nucl. Med., 25, 977. [Abstract]. 
Rendl, J.; Guthoff, R.; Schirbel, A.; Brechtelsbauer, D.; Schiller, D.; Seybold, S.; Schneider, P.; Lorenz, P.; Lieb, W. and Reiners, C. (2000), Iodine-123interleukin-2 (i-123-il-2) scintigraphy in Graves' ophthalmopathy (go): a new approach to assess disease activity. Endocr. J., 47, O-004. [Abstract].

Robb, R. J.; Greene, W. C. and Rusk, C. M. (1984), Low and high affinity receptors for IL-2. J. Exp. Med., 160s, 1126-1146.

Rolandsson, O.; Stigbrand, T.; Riklundahlstrom, K.; Eary, J. and Greenbaum, C. (2001), Accumulation of ${ }^{125}$ Iodine Labeled Interleukin-2 in the Pancreas of NOD Mice. J. Autoimmun., 17, 281-287.

Semenzato, G.; Zambello, R. and Pizzolo, G. (1992), Interleukin-2 receptor ewpression in health and disease. In- Waxman, J. and Balkwill, F. (eds.). Interleukin-2. Oxford: Backwell Scientific. pp. 78-105.

Signore, A.; Barone, R. and Procaccini, E. et al (1996), In vivo measurement of immunoglobulin accumulation in the pancreas of recent onset type 1 diabetic patients. Clin. Exp. Rheumatol., 14 : (Suppl 15), S41-S45.

Signore, A.; Chianelli, M.; Annovazzi, A.; Bonanno, E.; Spagnoli, L. G.; Pozzilli, P.; Pallone, F. and Biancone, L. (2000b), ${ }^{123}$ I-interleukin-2 scintigraphy for in vivo assessment of intestinal mononuclear cell infiltration in Crohn's disease. J. Nucl. Med., 41, 242-249.

Signore, A.; Chianelli, M.; Annovazzi, A.; Rossi, M.; Maiuri, L.; Greco, M.; Ronga, G.; Britton, K. E. and Picarelli, A. (1998), Imaging active lymphocytic infiltration in Coeliac disease with ${ }^{123}$ I-Interleukin-2 and its response to diet. Eur. J. Nucl. Med., 27, 18-24.

Signore, A.; Chianelli, M.; Annovazzi, A.; Rossi, M.; Maiuri, L.; Greco, M.; Ronga, G.; Britton, K. E. and Picarelli, A. (2000a), Imaging active lymphocytic infiltration in coeliac disease with iodine-123interleukin-2 and the response to diet. Eur. J. Nucl. Med., 27, 18-24.
Signore, A.; Chianelli M, Parisella MG, Giacalone P, Di Leve G, Barone R (1999), In vivo imaging of insulitis in autoimmune diabetes. $J$ Endocrinol Invest, 22, 151-158.

Signore, A.; Procaccini, E.; Annovazzi, A.; Britton, K. E.; Grossman, A. B.; Bonanno, E.; Maras, B.; Barra, D. and Pozzilli, P. (2002), ${ }^{123}$ I-InterLeukin-2: biochemical characterization and in vivo use for imaging autoimmune diseases. Nucl. Med. Commun. [in press].

Signore, A.; Picarelli, A.; Chianelli, M.; Biancone, L.; Annovazzi, A.; Tiberti, C.; Anastasi, E.; Multari, G.; Negri, M.; Pallone, F. and Pozzilli, P. (1996), 123IInterleukin-2 scintigraphy: a new approach to assess disease activity in autoimmunity. J. Pediatr. Endocrinol. Metab., 9, 139-144.

Signore, A.; Procaccini, E.; Annovazzi, A.; Chianelli, M.; van der Laken, C. and Mire-Sluis, A. (2000), The developing role of cytokines for imaging inflammatio and infection. Cytokines, 12 : (10), 1445-54.

Smith, K. A. (1988), Interleukin-2: inception, impact and implication. Science, 240, 1169-1176.

Van der Laken, C. J.; Boerman, O. C.; Oyen, W. J.; van de Ven, M. T.; van der Meer, J. W. and Corstens, F.H. (1998), Scintigraphic detection of infection and inflammation: new developments with special emphasis on receptor interaction. Eur. J. Nucl. Med., 25 : (5), 535-46.

Weiner, R. E. and Thakur, M. L. (1999), Imaging infection/inflammations. Pathophysiologic basis and radiopharmaceuticals. Q. J. Nucl. Med., 43 : (1), 2-8.

Received: July 09, 2002; Revised: July 12, 2002; Accepted: July 16, 2002. 